\title{
Healthcare governance, professions and populism: is there a relationship? An explorative comparison of five European countries
}

\section{Authors names and affiliations}

Emmanuele Pavolini ${ }^{1}$

Ellen Kuhlmann*2,3

Tuba I. Agartan 4,5

Viola Burau ${ }^{6}$

Russell Mannion ${ }^{7}$

Ewen Speed ${ }^{8}$

${ }^{1}$ Department of Political Science, Communication and International Relations, University of Macerata, Via Don Minzoni, 22, 62100, Macerata, Italy, Email: emmanuele.pavolini@unimc.it, Phone +390733 2582589

${ }^{2}$ Institute of Epidemiology, Social Medicine and Health Systems Research, Medical School Hannover, OE 5410, Carl-Neuberg-Str. 1, 30625 Hannover, Germany, Email: Kuhlmann.ellen@mh-hannover.de,Phone +49 5115325470

3 Medical Management Centre, Karolinska Institutet, Stockholm, Sweden, Email: ellen.kuhlmann@ki.se

${ }^{4}$ Takemi Fellow in International Health, Harvard T.H. Chan School of Public Health, 665 Huntington Ave., Building 1, Room 1210A, Boston, MA, 02115, Email: tagartan@hsph.harvard.edu, Phone +1 4017873106

5 Health Policy and Management Program, Providence College, 1 Cunningham Square, Providence, RI 02918, Email: tagartan@providence.edu

${ }^{6}$ Department of Public Health, Aarhus University, Bartholins Allé 2, DK-8000 Aarhus C, Denmark, Email: viola@ph.au.dk, Phone +45 93508709

${ }^{7}$ Health Services Management Centre, University of Birmingham, Park House, 40 Edgbaston Park Road, Birmingham B15 2RT, UK, Email: r.mannion@bham.ac.uk, Phone +44 121 4143404 
${ }^{8}$ School of Health and Social Care, University of Essex, Wivenhoe Park, Colchester, CO4 3SQ, UK, Email: esspeed@essex.ac.uk, Phone +44 1206872847

\section{* Corresponding author}

Ellen Kuhlmann, Institute of Epidemiology, Social Medicine and Health Systems Research, Medical School Hannover, OE 5410, Carl-Neuberg-Str. 1, 30625 Hannover, Germany, Email: Kuhlmann.ellen@mh-hannover.de,Phone +49 5115325470

\section{Acknowledgements}

We wish to thank our reviewers for very helpful comments. We also thank the participants of the European Health Policy Group Autumn Meeting held at the London School of Hygiene and Tropical Medicine, September 2017, for comments on a first version that focused on professional knowledge and New Public Management in relation to populism. TIA acknowledges support through the Takemi Fellowship Program at Harvard T. H. Chan School of Public Health, USA.

\section{Funding sources}

This comparative research did not receive any specific funding.

\section{Conflict of interest statement}

Declarations of interest: none 


\title{
Healthcare governance, professions and populism: is there a relationship? An explorative comparison of five European countries
}

\begin{abstract}
A new wave of support for populist parties and movements represents a serious threat to universal healthcare coverage in traditional liberal democracies and beyond. This article aims to contribute empirical material on the relationships between healthcare governance, professions and populism. It applies an explanatory cross-country comparative approach and uses mixed methods, including micro-level data garnered from international comparative databases and documents. Denmark, England, Germany, Italy and Turkey have been selected for comparison, reflecting different types of healthcare systems and populist movements. The results reveal variety in the ways populist discourses impact in healthcare. Abundant economic resources, network-based governance, high levels of trust in healthcare providers and doctors participating as insiders in the policy process seem to work as a bulwark against populist attacks on healthcare and professional expertise. On the other hand, poorly resourced NHS systems with doctors as outsiders in the policy process and major NPM reforms together with low to medium levels of trust in healthcare providers may be fertile ground for populist discourse to flourish. Our explanatory data provide hints of correlations, which may inform further studies to investigate causality. Yet the research highlights that healthcare governance and professions matter, and brings into view capacity for counteracting populist attacks on universal healthcare and professional knowledge.
\end{abstract}

\section{Keywords}

Health policy; Health professions; Healthcare governance; Populism; New Public Management reforms; European comparison

\section{Background}

Healthcare governance and policy in Europe have faced major challenges in responding to changing demographic needs and severe financial constraints [1]. A recent comparative analysis of 30 European countries, including all European Union EU-27 countries as well as Switzerland, Norway and Iceland, revealed that 'measures of quality of democracy and quality of government had many positive associations with process and outcome indicators of health policy' [2, p. 1298]. Simultaneously, a new wave of support for populist parties and movements 
represents a serious challenge to universal healthcare coverage in traditional liberal democracies [3-6]. Attendant risks for global health and public health have been highlighted [7-11]. Yet little attention has been focused on the complex connections between health policy, professions and populism. A direct connection is most clearly seen in the United States, where the Trump administration has attempted to abandon the Affordable Care Act reforms (Obamacare). The situation is far more complex in Europe. Many European Union (EU) countries and the wider European region are experiencing the growth of strong, often rightwing, populist movements. Nevertheless, the strength of populist movements varies significantly between countries, and a populist movement does not necessarily mean an immediate threat to universal healthcare coverage and an attack on the expertise and knowledge of health professionals. In Germany and Denmark, for instance, healthcare is backgrounded against populist attacks against the more traditional liberal institutions of the state.

This paper applies a cross-country comparative approach to help deepen our understanding of the relationship between healthcare governance, professions and prevailing populist discourses. The aim is to identify, from a health systems perspective, the propitious institutional conditions that facilitate populism. More specifically, we consider the role of health professions, especially medicine, in the growth of populist discourses in the governance of professional performance, particularly in relation to the ways in which populism has colonised the implementation of governance.

Clearly, governance is not the magic formula to explain highly complex conditions of growing populism and its impact in healthcare. Yet governance is a key policy lever to improve health systems performance [1] and may therefore provide deeper insights in the relationships. Specifically, the capacity of the health professions to act as 'trusted' policy experts and the importance of stakeholder participation are well known [12-16]. Research has also highlighted the transformative powers of new public management (NPM) policies and the changing involvement of doctors in clinical management and leadership [17-21]. These developments have not been previously analysed in relation to populist political parties and movements, but there are two obvious connections. First, populism and the changes in governance share a common goal, namely to tighten control of expert knowledge and professional practice [5, 6], albeit in varying ways and from different angles. Second, new public management, especially evidence-based medicine and policy-making, have transformed the connection between knowledge, professionalism and governance [22]. 
This article contributes new knowledge to debates about populism and explores empirically the relationship between healthcare governance, professions and populism. It seeks to identify hints of correlations which may inform further studies to identify causality. Three key questions/objectives guided the comparative research:

1) to explore the nature and effects of populism and set national populist discourses in the wider context of healthcare institutions and governance,

2) to draw a comparative map of selected populist discourses,

3) to highlight particular governance practices that may either constrain or nurture populist policies and programmes in healthcare and which serve to undermine to role of the health professions, especially the expert role of doctors.

\section{Methods}

This study is explorative in nature and, to our knowledge, the first effort to empirically investigate the relationships healthcare between governance, professions and populism. It applies a cross-country comparative approach and uses mixed methods, including micro-level data garnered from international comparative databases and documents. Five countries have been selected following a strategic (purposive) sampling approach [23], comprising Denmark, England, Germany, Italy and Turkey. This selection of countries reflects different types of healthcare systems - three types of NHS systems (Anglo-Saxon countries represented by England, Southern European countries by Italy, and Nordic countries by Denmark), a social insurance system with weak corporate actors in Turkey, and a corporatist system in Germany. It also reflects different forms and levels of democracy and success of populist movements. While England, Italy and Turkey have recently witnessed a growing influence of populist discourses and parties, this influence has been less influential in Denmark and Germany.

The first part of the paper is based on various quantitative analyses. In particular, microdata from the International Social Survey Programme (ISSP) survey of 2011 on 'health and healthcare' were used both at a descriptive level (table 2) and a multivariate level (this ostensibly comprised multinomial logit regressions). In particular, tables 3 and 4 synthetize the results of a set of regressions respectively on, the variables mostly associated to confidence, satisfaction and trust in the healthcare system and doctors in each country (table 3 ) and the relationship between voters' party preferences and the evaluation of how healthcare works in their country (table 4). For reasons of space, the tables just report the main results or our 
analysis. Annex I, available as online supplementary material, shows in more details the results of the regressions we have run.

The second part of the paper is qualitative and based on document analysis performed in spring 2018. The country-specific material was gathered by the authors who serve as country experts. A joint template was developed, based on major governance categories (Table 5; see also Box 1 for further explanations): the institutional contexts of the healthcare state, levels of trust in healthcare, the position of doctors in the governance arrangements, NPM reforms and stakeholder roles, the nature and content of the populist discourse and the key actors [24].

In our analysis we focus on the medical profession for two reasons: first, because of greater standardisation than other health professions and homogeneity across countries, and second, because of the leadership role and power of doctors in the health policy process. Despite growing relevance of other health professional groups, especially nurses [25], these processes have not essentially altered the dominance of the medical profession in influencing healthcare governance arrangements [26].

\section{Conceptualising populism in relation to healthcare and governance}

In the present paper we define populism as a discourse which raises two important questions about political process. It asks: 'who are the people' and 'who speaks for the people?' [27] (Panizza, 2005). In answering these questions, Albertazzi and McDonnell outline how populism 'pits a virtuous and homogeneous people against a set of elites and dangerous "others" who are depicted as depriving (or attempting to deprive) the sovereign people of their rights, values, prosperity, identity and voice' [28, p.3]. These processes are typically deployed to legitimise policy change, such as the apparent need for welfare chauvinism in containing access to statutory provision [29] in order to best reflect 'the volonté générale (general will) of the people' [30, see also 9]. Populism, therefore, entails an attempt to undermine the trust that the 'people' have in traditional liberal institutions. Here we use this definition of populism and explore how key health actors may be portrayed in populist discourse (Table 1).

Table 1. From a general populist discourse on politics and policy to a specific one on healthcare and health professionals

\begin{tabular}{|c|c|c|}
\hline $\begin{array}{c}\text { A general populist } \\
\text { discourse }\end{array}$ & $\begin{array}{c}\text { A specific populist discourse on healthcare and } \\
\text { health professionals }\end{array}$ & $\begin{array}{c}\text { Potential populist policy } \\
\text { solutions }\end{array}$ \\
\hline
\end{tabular}




\begin{tabular}{|c|c|c|}
\hline $\begin{array}{l}\text { Institutional } \\
\text { distrust }\end{array}$ & $\begin{array}{l}\text { Institutional distrust focused on specific healthcare } \\
\text { institutions and professions or distrust in healthcare } \\
\text { institutions and professions as a "simple" result of a } \\
\text { general pattern of institutional distrust }\end{array}$ & \\
\hline $\begin{array}{l}\text { The corrupted } \\
\text { 'elites' }\end{array}$ & $\begin{array}{l}\text { - Doctors } \\
\text { - Managers/Bureaucrats } \\
\text { - Politicians in charge of governing healthcare } \\
\text { - The State } \\
\text { - Private providers } \\
\text { - 'Big Pharma' }\end{array}$ & $\begin{array}{l}\text { - More freedom of choice for } \\
\text { the "people" (consumerism) } \\
\text { - More direct control of the } \\
\text { "people" on all the } \\
\text { healthcare actors } \\
\text { (empowerment) } \\
\text { - Less State involvement in } \\
\text { healthcare (although not } \\
\text { always the case) }\end{array}$ \\
\hline \multirow{2}{*}{ The 'outsiders' } & $\begin{array}{l}\text { - Patients who are "outsiders" (migrants, people } \\
\text { belong to minorities) behave as "free riders": they } \\
\text { take more out than they put in and they try to exploit } \\
\text { their position }\end{array}$ & - 'Welfare chauvinism' \\
\hline & $\begin{array}{l}\text { - Health professionals who are 'outsiders' (migrants, } \\
\text { people who belong to minorities) steal jobs from the } \\
\text { (unemployed) 'people' }\end{array}$ & $\begin{array}{l}\text { - Restricting the access of } \\
\text { 'outsiders' to the healthcare } \\
\text { labour market }\end{array}$ \\
\hline
\end{tabular}

Source: authors' own table based on the literature

Populist notions of 'corrupted elites' in healthcare may refer to the following actors. Doctors, portrayed as exploiting their knowledge and position in order to gain more power and economic resources at the expenses of patients (the 'people') [3, 9]. This rhetoric is evident in the drive to patient-centred medicine [31]. Similarly, healthcare managers and bureaucrats exploiting their position in order to improve their economic well-being through NPM governance. Moreover, they may be all be accused of being corrupt in relation to aligning with private commercial interests who seek to sell their products into public healthcare systems. Furthermore, populists might portray 'big pharma' companies, or private healthcare providers as selling useless and/or dangerous healthcare cures [32] perhaps in order to make a profit. Moreover, populist rhetoric may focus more generally on the genitive role of the state, which takes away freedom of choice in healthcare from the 'people' and makes these decisions on their behalf.

In addition, so called 'outsiders' (e.g. migrants, black and minority ethnic groups) may be the focus of the populist discourse in relation to entitlement and access to healthcare. Outsiders can be portrayed as individuals exploiting their access to healthcare (i.e. not paying enough for the extensive use they make of it) and thereby making healthcare more expensive to the general population. 'Outsiders' could also be depicted as being a threat to healthcare workers, as outsiders may be portrayed as taking away jobs from the 'people' or creating an 'unfair' level of competition for health and social care jobs, through an often-repeated rhetoric around their 
enforced acceptance of lower wages, or their purported willingness to work under worse labour contracts.

A populist discourse in relation to healthcare highlights the following 'diagnosis' and 'policy solutions' to the problems raised:

- The 'diagnosis': it is not simply an issue of how much a country allocates for healthcare, but how the resources are spent and the role played by 'elites' and 'outsiders' in distorting the allocation and use of scarce healthcare resources. In relation to public expenditure on healthcare the discourse might be different depending on the populist party: some parties might advocate for more expenditure (although through a chauvinist pattern), while others might argue it is better to spare resources and allow individuals and households to choose more freely by themselves.

- The 'policy proposal': a mix of consumerism and empowerment, transferring more power to the 'people', coupled with 'welfare chauvinism' and limitation to 'outsiders' employment in the field. The result may be a universalistic access to healthcare for the 'people', which, necessarily excludes those sections of the general population deemed as 'outsiders'.

It is important to emphasise that a populist discourse in relation to healthcare will be selective, focusing on certain outsiders and elites and proposing a different mix of solutions between consumerism, empowerment, welfare chauvinism and limitations on the access of 'outsiders' to participate in the healthcare labour market. Thus the success depends on the populist party's capacity and willingness to mobilise different social groups [33].

However, we assume that the effects of populism depend at least to some degree on the institutions of the healthcare system and the governance models. We refer to governance in a broad sense as a framework for negotiating policy interventions [1] and 'navigating complex relationships' [34, p.4]. Governance serves our analysis as a methodological framework, because it offers a systematic approach to investigate complexity across macro-micro levels of policy-making and stakeholder and workforce groups [1,35-36], and facilitates comparative, health systems-based analysis [20]. As a methodological tool governance may therefore provide some guidance on how to identify empirical indicators in a situation where both models and data are lacking (see Box 1). 
Box 1: Dimensions of governance and the assumed effects on populism

Health system characteristics define the macro-level conditions and framework for governance, which shape the opportunities of populist agendas. Data on how this happens are currently lacking. We therefore use a comparative design including different types of healthcare systems to identify dimensions of governance which might have an effect on the power of populist agendas and their impact in healthcare.

New Public Management (NPM) has shifted decision-making powers from the system level (macrolevel) to the meso-level of healthcare organisations. A common goal of NPM policies is to improve efficiency of healthcare provision by improving control and accountability of the health professionals; the professions are therefore target groups of NPM, which might affect the ways populist agendas matter in healthcare.

Health professions and professionalism are the backbone of healthcare and important stakeholders, who serve as policy experts and knowledge producers. The different populist agendas share a common 'enemy', namely expert knowledge and scientific evidence. Health professional groups and strong professionalism might therefore act as a barrier against populism.

Trust may serve as a micro-level indicator of the public sentiment, and some comparative data from polls are available which allow for comparison. Trust is a highly complex concept, yet one general assumption is that lack of citizens' trust in government, or more generally in the state, may open the door for populist agendas.

\section{Results}

\section{Comparing trust in healthcare provision and professionals}

Trust plays an important role in healthcare as a buffer to social conflict. Across countries, professionals, especially doctors, are among the most trusted groups [37]. We use survey data to empirically define and compare the relationship between trust and health professionals. Four questions in the ISSP 2011 survey on 'health and healthcare' are important: confidence in the national healthcare system; satisfaction with the national healthcare system; trust in doctors; agreement with the sentence 'Doctors care more about earnings than patients'.

These four items have been used in the following way. Table 2 describes how many people agree with the four statements. Table 3 reports the results of multivariate regressions indicating which variables are more significant in explaining the differences in each country in terms of trust and satisfaction with the national healthcare system and the professionals. Table 4 adopts a different perspective in order to obtain a broader view. The dependent variable becomes which party is voted for; among the independent variables there are the four items evaluating the healthcare system functioning and doctors' behaviours.

Denmark is the country where the population have more confidence in healthcare and doctors and they are generally satisfied with how their own system works. Turkey is in second place: 
although it has a relatively high share of people who trust doctors $(74.7 \%)$, most believe that doctors care more about their own earnings than the welfare of their patients. Italy is the country with the lowest level of trust and satisfaction across all four items. Germany and UK lay between the other countries.

Table 2. Confidence, satisfaction and trust in the healthcare system and doctors (year 2011)

\begin{tabular}{|l|c|c|c|c|}
\hline Country & $\begin{array}{c}\text { Confidence in the } \\
\text { national } \\
\text { healthcare system }\end{array}$ & $\begin{array}{c}\text { Not satisfied with } \\
\text { the healthcare } \\
\text { system in own } \\
\text { country }\end{array}$ & $\begin{array}{c}\text { Doctors can be } \\
\text { trusted }\end{array}$ & $\begin{array}{c}\text { Doctors care more } \\
\text { about earnings }\end{array}$ \\
\hline Denmark & 57.7 & 20.4 & 79.1 & 23.2 \\
\hline Germany & 40.3 & 40.5 & 66.2 & 30.2 \\
\hline Italy & 19.7 & 51.5 & 53.4 & 38.7 \\
\hline Turkey & 52.8 & 36.4 & 74.7 & 41.9 \\
\hline UK & 31.3 & 26.3 & 76.2 & 15.7 \\
\hline
\end{tabular}

Source: authors' elaboration, based on ISSP 2011 micro-data

The main independent variables associated with the four views about healthcare and professionals change from one issue to the other and between countries. Nevertheless, several important recurrent patterns emerge (Table 3). A good health status, the feeling of happiness and, even more importantly, the recent use of healthcare services (from primary care to hospitalisation) are all associated with better evaluations of the healthcare system and doctors.

Those who use healthcare have in general more positive views about it. Yet in Turkey this mechanism is reversed for the case of doctors; in Germany and Denmark more frequent healthcare users are more likely to highlight personal economic interests of doctors but maintain a good level of trust. Often distrust and low satisfaction seem to arise not from direct experience but more often from a general view on institutions [38], with a generalised level of low satisfaction and mistrust, with healthcare being one of them. Age and education (including those who are still studying) are variables positively correlated with satisfaction and trust, again with the partial exception of Turkey in relation to education. Another variable associated to distrust is unemployment. Gender seems to play a role only in relation to a lower female satisfaction with their own healthcare system in most countries.

In sum, those experiencing economic difficulties and perhaps feeling most 'left behind' by the state tend to have negative perceptions of the healthcare system and the professionals working in it (apart from the case of Turkey). It is important to note that these results are independent from the actual use of healthcare: this variable is positively associated to trust and satisfaction. 
Table 3. Confidence, satisfaction and trust in the healthcare system and doctors: a synthesis of the regressions' results

\begin{tabular}{|c|c|c|c|c|c|c|c|c|c|c|c|c|c|c|c|c|c|c|c|c|}
\hline $\begin{array}{l}\text { Independent } \\
\text { variables }\end{array}$ & \multicolumn{5}{|c|}{$\begin{array}{c}\text { Confidence in the national } \\
\text { healthcare system }\end{array}$} & \multicolumn{5}{|c|}{$\begin{array}{l}\text { Satisfied with the healthcare } \\
\text { system in own country }\end{array}$} & \multicolumn{5}{|c|}{ Doctors can be trusted } & \multicolumn{5}{|c|}{$\begin{array}{c}\text { Doctors care more about } \\
\text { earnings }\end{array}$} \\
\hline & Dk & $\mathrm{Ge}$ & It & $\mathrm{Tk}$ & $\begin{array}{l}\mathrm{U} \\
\mathrm{K}\end{array}$ & Dk & $\mathrm{Ge}$ & It & $\mathrm{Tk}$ & $\begin{array}{l}\mathrm{U} \\
\mathrm{K}\end{array}$ & Dk & $\mathrm{Ge}$ & It & $\mathrm{Tk}$ & $\begin{array}{l}\mathrm{U} \\
\mathrm{K}\end{array}$ & $\mathrm{Dk}$ & $\mathrm{Ge}$ & It & Tk & $\begin{array}{l}\mathrm{U} \\
\mathrm{K}\end{array}$ \\
\hline $\begin{array}{c}\text { Education } \\
\text { (level) }\end{array}$ & & & & - & & & & & - & & + & & + & - & + & - & - & - & & - \\
\hline $\begin{array}{l}\text { Sex } \\
(\mathrm{F})\end{array}$ & & & & & & - & - & - & - & & & & & & & & & & & \\
\hline $\begin{array}{l}\text { Age } \\
\text { (years) }\end{array}$ & & & & + & + & + & + & + & + & + & + & + & + & + & + & & & & & - \\
\hline $\begin{array}{l}\text { Health } \\
\text { status }\end{array}$ & + & + & + & & & + & + & & + & + & + & + & & & & - & - & - & - & \\
\hline Happiness & + & + & + & + & + & + & + & + & + & + & + & + & + & + & + & - & - & & & \\
\hline $\begin{array}{l}\text { Healthcare } \\
\text { use }\end{array}$ & & + & + & & + & + & + & & & + & & + & & - & + & - & - & & & \\
\hline $\begin{array}{l}\text { Person in } \\
\text { education }\end{array}$ & + & + & & & + & & & & & & & & & & & & & & & \\
\hline $\begin{array}{c}\text { Domestic } \\
\text { work }\end{array}$ & & & & + & & & & & + & & & & & & & & & & & + \\
\hline $\begin{array}{c}\text { Unemploye } \\
\mathrm{d}\end{array}$ & & & & & & - & & & & & - & & & & & + & & + & & + \\
\hline
\end{tabular}

+ means a positive and significant correlation between the independent variable and the dependent one;

- means a negative and significant correlation between the two variables.

Source: authors' elaboration based on ISSP 2001 micro-data; the regressions results with detailed information on coefficients and significance can be looked at in Annex 1 in the online supplementary material

Table 4 goes one step further and shows the relationship between individuals' political party preferences and the evaluation of how healthcare works in a given country. Using as a base reference Left - Center Left parties, we can see that Centre-Liberal parties' voters as well as Conservative parties' voters are often as much satisfied and have confidence in the healthcare system and doctors as those voting for Centre-Left parties, if not more in some countries (the UK and Turkey). Both far Right parties and Far Left parties (when data are available and usable due to a large enough sample size) appear to attract individuals who are more critical of the healthcare system (with the exception of Turkey) and the role of doctors. The same applies to other parties, in particular the Five Stars Movement in Italy which is often portrayed as a populist party.

Table 4. Healthcare variables associated to the choice among political parties (m-logit regressions models; base outcome category: Left - Center Left parties)

\begin{tabular}{|c|c|c|c|c|c|c|c|c|c|c|c|c|c|c|c|c|c|c|c|c|}
\hline $\begin{array}{l}\text { Independent } \\
\text { variables }\end{array}$ & \multicolumn{5}{|c|}{$\begin{array}{c}\text { Confidence in the national } \\
\text { healthcare system }\end{array}$} & \multicolumn{5}{|c|}{$\begin{array}{l}\text { Satisfied with the healthcare } \\
\text { system in own country }\end{array}$} & \multicolumn{5}{|c|}{ Doctors can be trusted } & \multicolumn{5}{|c|}{$\begin{array}{c}\text { Doctors care more about } \\
\text { earnings }\end{array}$} \\
\hline & Dk & $\mathrm{Ge}$ & It & Tk & UK & $\mathrm{Dk}$ & $\mathrm{Ge}$ & It & $\mathrm{Tk}$ & UK & Dk & $\mathrm{Ge}$ & It & Tk & UK & Dk & $\mathrm{Ge}$ & It & Tk & $\begin{array}{l}\mathrm{U} \\
\mathrm{K}\end{array}$ \\
\hline $\begin{array}{l}\text { Far } \\
\text { left }\end{array}$ & $=$ & $=$ & $=$ & & & - & - & - & & & $=$ & $=$ & $=$ & & & $=$ & $=$ & $=$ & & \\
\hline $\begin{array}{l}\text { Center } \\
\text { Liberal }\end{array}$ & $=$ & $=$ & & & $=$ & $=$ & + & & & + & $=$ & $=$ & & & $=$ & $=$ & $=$ & & & $=$ \\
\hline $\begin{array}{c}\text { Right } \\
\text { Conservativ } \\
\mathrm{e} \\
\end{array}$ & $=$ & $=$ & $=$ & + & $=$ & $=$ & + & $=$ & + & + & + & $=$ & $=$ & $=$ & + & $=$ & $=$ & $=$ & - & $=$ \\
\hline $\begin{array}{c}\text { Radical } \\
\text { Right }\end{array}$ & $=$ & & & + & & - & & & + & & $=$ & & & - & & $=$ & & & $=$ & \\
\hline
\end{tabular}




\begin{tabular}{|c|l|l|l|l|l|l|l|l|l|l|l|l|l|l|l|l|l|l|l|l|}
\hline $\begin{array}{c}\text { Other } \\
\text { Parties* }\end{array}$ & & & $=$ & & $=$ & & & - & & $=$ & & & - & & $=$ & & & $=$ & & $=$ \\
\hline
\end{tabular}

Note: blank cells when data missing or sample size too small (below 30 individuals).

+ means a positive and significant correlation between the independent variable and the dependent one;

- means a negative and significant correlation between the two variables;

$=$ means no significant correlation between the two variables.

* Five Stars Movement for Italy and UKIP and other parties for the UK.

Source: authors' elaboration based on ISSP 2011 micro-data

\section{Healthcare governance, populist discourses and actors: contextualising the relationship}

This section illustrates different topics of the analysis (based on document analysis with the country-specific material gathered by the authors who serve as country experts) followed by a summary of the main results in Table 5.

- Healthcare governance and expenditure

The UK National Health Service is largely financed through general taxation, providing free universal (primary and secondary) healthcare, with little recourse to user charges. Historically, the NHS system of governance has involved strong central government control with local agencies taking responsibility for local planning. However, since the early 1990s a series of reforms have gradually extended market mechanisms into the organisation and delivery of health services [39, 40]. Italy has also a NHS, introduced in 1978, which was until the early 1990s run mostly by the central government. Since then, several reforms introduced which have increased decentralisation, expanded marketisation and strengthened managerialisation [41].

Like Italy, Denmark has a decentralised NHS: five regions are responsible for providing hospital services and for contracting general practitioners, while municipalities offer health promotion and non-medical primary care services. The last decade has seen increasing centralisation; for example, funding primarily comes from national taxes that central government uses to define the substance of health services. This co-exists with elements of marketisation and managerialisation, like incentive payments of hospitals and purchaserprovider splits at the municipal level $[42,43]$.

Germany is the classic model of a Bismarckian social health insurance system (SHI) with joint self-administration of the SHI funds and the SHI Physicians Associations. The medical profession represents the provider side and has strong self-governing powers, while nurses and other health professions have weak stakeholder positions. Federalism, decentralisation and 
partnership or network-based governance are increasingly coupled with market mechanisms $[26,44]$.

Before the 2003 reforms, Turkey had a mix of social health insurance organised by nonprofit insurance funds and a tax-financed primary care system. Since the reforms, it has evolved into a national health insurance system, with a single payer that is responsible for strategic purchasing from private and public providers. The medical profession and other health professions were not accorded a central role in the governance of the healthcare system, which is still dominated by a strong central government [45].

The five countries show marked differences in terms of public per capita expenditure: the UK NHS spends far less than Germany and Denmark, and more than Italy and Turkey. The latter is the country that spends the least by far. The average yearly per capita expenditure growth in real terms in the last ten years (2007-2016) was around $+1.5 \%$ in Denmark and $+1,6 \%$ in the UK, higher in Turkey $(+2.8 \%)$ and Germany $(+3.5 \%)$ and negative in Italy $(-0.3 \%)$.

- NPM reforms and the position of doctors in the governance arrangements

From the 1980s onwards both the UK NHS and, starting a decade later, the Italian health system have been subject to extensive managerial control and marketised restructuring as part of wider NPM trends. These include the creation of a purchaser-provider split in the organisation and delivery of services within the NHS (more in the UK case), tighter performance measurement and management arrangements, often tied to payment for performance incentives and increasing use of private providers and the expansion of a mixed economy of care $[39,41,46]$.

These changes have affected doctors in both countries. From their inception, doctors had to be coerced into the new NHS structure, and many family doctors remain as independent contractors, not salaried employees of the NHS. There has also been significant recent reforms of professional regulation and oversight, including more extensive methods of measuring and assessing organisational and individual performance, tighter clinical governance arrangements and the use of financial incentives to drive performance improvements. This has led to a range of market, corporate and professional logics ([47] for the UK; [21] for Italy) and also to new forms of involving doctors in management [18]. 
In comparison, NPM reforms in Demark have been more muted [42, 43]. In relation to hospitals this has included partial funding based on diagnose-related groups (DRGs), waiting time guarantees, a national system of quality-based accreditation as well as national care pathways for major diseases like cancer. Similarly, many municipalities have introduced a purchaserprovider split. General practice has largely remained untouched by NPM and has only recently been included in the national system of quality-based accreditation. The consensus orientation continues to be strong across different levels of the healthcare system and gives doctors ready access to political and administrative decision making ('public corporatism'). This integration of doctors works as a buffer against more radical reforms including professional governance. The National Board of Health, an independent public agency under the Department of Health, is responsible for maintaining the professional registry and for dealing with cases of professional misconduct, and there is no separate system of clinical governance.

In Germany a number of the NPM reforms have been introduced from the 2000s onwards [44]. Characteristically, new forms of governing the performance of healthcare providers have been established and management and market logics strengthened. However, this has happened without any radical interventions in the governance system of joint-self-administered SHI funds and SHI Physicians Associations, and it has not radically changed medical power and the position of doctors as insiders in the policy process [22].

In Turkey, health reform debates since the mid-1980s have featured large in NPM ideas, such as encouraging competition through purchaser-provider split, expanding the role of private sector, reorganising the Ministry of Health, expanding the role of professional managers and experimenting with financial incentives to improve provider performance. But it was the 2003 Health Transformation Program that implemented many of these ideas systematically in the healthcare system [48]. The post-2003 reforms also placed a new emphasis on the role of the patient-consumers through new mechanisms, such as patient rights' units in the hospitals or a telephone hotline to enable direct expression of views and complaints [49]. At the same time, the reforms questioned the legitimacy of professional organisations, such as the Turkish Medical Association and some of the major unions, often describing them as self-interested actors [24]. Health professionals have remained at the margins of healthcare policy, with a clear trend towards centralisation and managerialism in post-2003 governance arrangements [45, 48]. 
- Populist parties and the characteristics of populist discourse in relation to healthcare governance and professionals

All five countries considered have populist parties. In Denmark, the Danish People's Party (Dansk Folkeparti) is the main populist party. It gained more than $21 \%$ of the popular vote, making it the second largest party after the Social Democrats at the last election. Since 2003 the party has also played an influential role in its support of centre-right minority coalition governments. In Germany the only relevant populist party is the radical right 'Alternative für Deutschland' (AfD). In the UK the primary populist right-wing party is UK Independence Party (UKIP). In the 2015 General Election it accounted for over $12 \%$ of the popular vote and in the last European Parliament election, it became the largest UK representative, thanks to a $26 \%$ share of the popular vote. In Italy there are two main populist parties: The 'League' Party and the Five Stars Movement (FSM). Both parties were among the most voted for parties at the March 2018 general election: respectively they collected 17\% and 32\% of the total votes and are now part of the same government coalition. In Turkey, the governing Justice and Development Party (JDP) is a conservative right-wing party, which received $49.5 \%$ share of the popular vote at the November 2015 general election. While the party's share declined to $42.5 \%$ in the 2018 elections, it formed an alliance with the Nationalist Action Party and together they were able to constitute the majority in the Parliament with $52.5 \%$ of the popular vote. JDP has used a peculiar combination of economic and social security reforms that was often described as 'populist' or 'neopopulist' in the sense, that the party developed personalistic ties to the disadvantaged masses while implementing neoliberal market reforms [50].

In exploring the nature of populist discourse across the five countries in relation to healthcare, we see a number of important differences. On the one hand, in Denmark and Germany, the prevailing populist discourse is not specifically related to healthcare. There is also little sign that populist parties are seeking to portray doctors as part of the 'corrupted elites'. However, migrants and asylum seekers are portrayed as the 'outsiders' who take away the resources and welfare benefits from German citizens, yet this is not connected to healthcare. Asylum seekers have access to basic healthcare in both countries [51]. In Germany, the programme of the AfD mentions health policy only briefly and in relation to policy aims which are widely accepted across the different parties and within the population: community-based medical care (wohnortnahe medizinische Versorgung), more doctors for rural areas, and support and expansion of the caring professions. The positive rhetoric is in stark contrasts to other 
programmatic policy goals of the AfD, usually framed as 'anti' approaches (e.g. restricting the number of asylum seekers, closing borders).

The lack of interest in using healthcare to animate a populist discourse in Denmark and Germany is in stark contrast to the UK, Italy and Turkey, where healthcare has played a key role in fuelling populist discourses. In all three countries we found a strong connection between the metaphor of 'corrupted elites' and populist parties. In Italy and Turkey this discourse focusses on the national level, while it has a strong anti-EU approach in the UK. This strong anti-EU approach ('corrupted elites in Brussels') merges with a discourse of the EU citizens and the migrants as 'outsiders', who are portrayed as taking away benefits from sovereign citizens of the UK. This nationalist discourse is especially powerful, because close identification with the NHS is widespread in the UK and serves as a resource for those wishing to manipulate and shape national identities (portraying the EU citizens as outsiders). Widely perceived to be a national treasure [52], these populist appeals promoted the image of a struggling health service that would be thriving, if it were not for the technical 'Eurocrats' demanding exorbitant payments.

The most immediate example of the intersection between populism and healthcare in the UK is the central role that the discourse around funding of the NHS played in the 2016 UK European Union Membership referendum (Brexit [53]). The Vote Leave campaign claimed that $£ 350$ million was paid weekly to the EU, and that, post-referendum, this would be redirected to the NHS. This idea of an underfunded service also aligned with wider appeals for welfare nativism and conditionality [3], as migrants or 'health tourists' (European or otherwise) were presented as a drain upon a struggling health service. In turn, these appeals perpetuated a right-wing populist agenda, predicated on a claimed need to limit access to healthcare, evidenced in attempts to reclaim the costs of so-called health tourism from non-UK residents using the NHS [54].

In Turkey, by contrast, the 'outsider' discourse does not play any relevant role. Particularly in the earlier stages of health reforms when the transfer of hospitals to the Ministry of Health or full-time work requirements in public facilities were debated, Turkish populist discourse primarily constructed doctors as corrupted elites, who are self-interested. Some leaders of the Turkish Medical Association were also accused of being 'anti-national' when they criticized the government's policies related to democratic rights. Justice and Development Party's anti- 
institutionalist tendencies were most evident in relation to the role of professional associations, which were originally imagined as corporatist partners in the context of the social insurance tradition dating back to the early days of the Republic.

More recent debates suggested the introduction of new regulations relating to the titles of these professional organisations, elections, and membership rules such as ending mandatory membership requirements for private sector physicians [55]. The Turkish case study revealed that populism may 'grow up in the shadow of new public management' and governance reforms [24]. Importantly, it may well co-exist with a commitment to strengthen universal healthcare coverage. What mattered most in these processes were not the policies themselves, but the ways new managerialist policies were implemented in the healthcare system [24]. The findings highlight that the link between new governance and populisms is the common attempt to transform the role of professions as 'mediators' between the state and the citizens. It may therefore be the case that NPM has served to open the door for populist leaders to present themselves as the 'real champions' of the people.

The Italian populist discourses surrounding healthcare have, on the whole, a strong antiinstitutionalist and anti-Public Health focus. The Five Stars movement (FSM) has focused on developing a narrative around the 'corrupted elites' in healthcare. The party also supported the so-called 'No-Vax' (No-Vaccination) movement. The whole debate started in Summer 2017 when the National Parliament passed a law concerning healthcare prevention. This law made ten different types of vaccines compulsory for children who want to access nurseries and kindergartens as well as for students under 17 years old. The No-Vax movement was against this policy, arguing that there might be a positive correlation between vaccination and increased incidence of other diseases. Despite strong and vociferous arguments against the scientific and medical community, the primary focus of the No-Vax movement was on accusing doctors of being interested in doing business with 'big pharma'.

Conversely, the populist discourse of the 'League' Party, was based on the allegedly negative effects of 'outsiders' and less focused on attacking the 'corrupted elites'. Migrants are seen as a source of costs for the healthcare system and, therefore, 'welfare chauvinism' and the reduction of the presence of migrants was a key element in the party discourse. Within this populist discourse, the 'League' has tried to attract voters from the No-Vax debate and often declared that the 2017 bill on compulsory vaccination will be erased [56]. 
Table 5. Institutional contexts, healthcare governance and populism

\begin{tabular}{|c|c|c|c|c|c|}
\hline & Denmark & UK & Germany & Italy & Turkey \\
\hline Governance & $\begin{array}{l}\text { Decentralised NHS; } \\
\text { public corporatist } \\
\text { governance; } \\
\text { contracted, self- } \\
\text { employed GPs }\end{array}$ & & $\begin{array}{c}\text { Corporatist SHI } \\
\text { system; network } \\
\text { governance with joint } \\
\text { self-administered SHI } \\
\text { funds and SHI } \\
\text { Doctors with some } \\
\text { market; free choice of } \\
\text { providers and } \\
\text { insurance funds, no/ } \\
\text { weak gatekeeping in } \\
\text { primary care }\end{array}$ & $\begin{array}{l}\text { Regionalised NHS; } \\
\text { contracted-out self- } \\
\text { employed GPs; an } \\
\text { increasing role of } \\
\text { private contracted-out } \\
\text { provision }\end{array}$ & $\begin{array}{l}\text { SHI with a single } \\
\text { payer, combining } \\
\text { hierarchy and market } \\
\text { modes of governing; } \\
\text { majority of physicians } \\
\text { work in the public } \\
\text { sector, no/weak } \\
\text { gatekeeping in } \\
\text { primary care }\end{array}$ \\
\hline $\begin{array}{l}\text { Average } \\
\text { annual } \\
\text { growth rate } \\
\text { of public } \\
\text { expenditure, } \\
\text { per capita in } \\
\text { real terms } \\
(2007-2016) \\
\end{array}$ & 1.5 & 1.6 & 3.5 & -0.3 & 2.8 \\
\hline $\begin{array}{l}\text { Public } \\
\text { expenditure } \\
\text { (per-capita } \\
\text { PPP) (2016) }\end{array}$ & 4,374 & 3,320 & 4,695 & 2,545 & 863 \\
\hline $\begin{array}{l}\text { Trust in } \\
\text { doctors and } \\
\text { healthcare }\end{array}$ & Medium-High & Medium & Medium & Low & Medium-High \\
\hline $\begin{array}{l}\text { Position of } \\
\text { doctors in } \\
\text { governance }\end{array}$ & $\begin{array}{l}\text { Doctors as insiders in } \\
\text { political- } \\
\text { administrative } \\
\text { decision-making } \\
\text { across levels }\end{array}$ & & $\begin{array}{l}\text { Doctors as insiders in } \\
\text { the policy process }\end{array}$ & $\begin{array}{c}\text { Doctors as only } \\
\text { partially insiders in } \\
\text { the policy process } \\
\text { (from a doctor-centred } \\
\text { NHS to a more } \\
\text { contested managers- } \\
\text { led NHS) }\end{array}$ & $\begin{array}{l}\text { Not integrated; self- } \\
\text { governance very } \\
\text { limited; doctors in } \\
\text { public hospitals are } \\
\text { salaried civil servants; } \\
\text { chief physician is } \\
\text { responsible for the } \\
\text { governance of medical } \\
\text { services in public } \\
\text { hospitals, combining } \\
\text { some elements of } \\
\text { professional authority } \\
\text { and values with } \\
\text { managerial priorities }\end{array}$ \\
\hline $\begin{array}{l}\text { NPM } \\
\text { reforms and } \\
\text { changes in } \\
\text { the } \\
\text { involvement } \\
\text { of } \\
\text { stakeholders }\end{array}$ & $\begin{array}{l}\text { Individual reforms } \\
\text { drawing on selected } \\
\text { elements of } \\
\text { marketisation and } \\
\text { managerialism; } \\
\text { involvement of } \\
\text { doctors in public } \\
\text { corporatism remains } \\
\text { strong }\end{array}$ & & $\begin{array}{l}\text { NPM reforms focus } \\
\text { on organisational } \\
\text { change to improve } \\
\text { integration without } \\
\text { changing the pillarised } \\
\text { system of corporatist } \\
\text { actors; strong medical } \\
\text { profession }\end{array}$ & $\begin{array}{c}\text { Increasing } \\
\text { managerialisation and } \\
\text { still a limited role of } \\
\text { civil society } \\
\text { stakeholders; patients } \\
\text { caught between } \\
\text { managers and } \\
\text { professionals' power }\end{array}$ & $\begin{array}{c}\text { NPM reforms } \\
\text { transformed the bonds } \\
\text { between the state and } \\
\text { the professions } \\
\text { through changes in the } \\
\text { governance of } \\
\text { hospitals, payment } \\
\text { methods and } \\
\text { complaint } \\
\text { mechanisms } \\
\end{array}$ \\
\hline $\begin{array}{l}\text { Content of } \\
\text { populist } \\
\text { discourse }\end{array}$ & $\begin{array}{c}\text { Healthcare and } \\
\text { doctors remain outside } \\
\text { the populist discourse; } \\
\text { migrant access to and } \\
\text { use of healthcare is } \\
\text { not a concern }\end{array}$ & & $\begin{array}{l}\text { Healthcare and } \\
\text { doctors do not play a } \\
\text { role; the use of } \\
\text { healthcare by migrants } \\
\text { is not a concern }\end{array}$ & $\begin{array}{c}\text { Healthcare and } \\
\text { doctors as an } \\
\text { important target } \\
\text { (corrupted elites); } \\
\text { welfare chauvinism } \\
\text { (by the League); more } \\
\text { freedom of choice for } \\
\text { citizens and less } \\
\text { interference from } \\
\text { professionals (e.g. } \\
\text { vaccination) } \\
\end{array}$ & $\begin{array}{l}\text { Populist discourse } \\
\text { strong targeting } \\
\text { healthcare service } \\
\text { delivery and doctors } \\
\text { as self-interested } \\
\text { actors and } \\
\text { empowering patients } \\
\text { as consumers }\end{array}$ \\
\hline $\begin{array}{l}\text { Populist } \\
\text { actors }\end{array}$ & $\begin{array}{l}\text { Dansk Folkeparti } \\
(21 \%, 2015)\end{array}$ & UKIP $(12 \%, 2015)$ & $\begin{array}{c}\text { Alternative für } \\
\text { Deutschland (AfD) } \\
(13 \%, 2018)\end{array}$ & $\begin{array}{l}\text { Five Stars Movement } \\
(32 \%, 2018) ; \text { the } \\
\text { League }(17 \%, 2018)\end{array}$ & $\begin{array}{c}\text { Justice and } \\
\text { Development Party } \\
(42.5 \%, 2018) \text { and } \\
\text { alliance with } \\
\text { Nationalist Action } \\
\text { Party }(52.5 \%, 2018) \\
\end{array}$ \\
\hline
\end{tabular}

Sources: authors' own table 


\section{Discussion}

Our comparative overview of the context of healthcare and governance in the five selected European countries reveals a wide variety of populist discourses and appeals. This is an important finding, because it highlights the need for a more context-specific and sensitive approaches to studying relationships between populism, professions and healthcare. Yet our comparison also highlights important institutional conditions that may nurture populist discourses.

In Germany and Denmark, a strong cultural value of perceiving healthcare as public good provided for all citizens, alongside a strong public/mandatory economic investment in healthcare, may attenuate the appeals of populism. Especially in Germany, high levels of per capita expenditure, free choice of providers and the corporatist governance arrangements with doctors as an independent pillar and strong tradition of self-employment in ambulatory care may prevent an anti-institutionalist and 'elite' rhetoric from prevailing. It is also notable that populism is far stronger in the Eastern parts of Germany, yet once again, healthcare does not serve well to construct the Eastern citizens as 'losers', as they show overall higher rates of usage of healthcare and pharmaceuticals compared to the Western parts of Germany. However, growing verbal and physical violence against health professionals in the emergency services (as well as against fire fighters and policemen) has been reported, although not to the same extent as it is occurring in several other countries, including for instance Turkey [57].

In the UK, the role of the NHS as a cherished national symbol of healthcare provision embodies the risk of being aligned with nationalist discourses, and related to this, of 'outsiders' who exploit the NHS to the disadvantage of the British people. Here, a traditional British nationalism serves to construct the EU as a 'corrupted elite' and the EU citizens and migrants as 'outsiders'. In Turkey, the traditionally weak presence of corporatist actors [45] opens a door for populist discourses to slip in. Within this context the medical profession serves as a proxy for the 'corrupt elites' especially in debates on efficient service provision and performance based payments. In Italy, the austerity cuts in the recent decade to a healthcare system, which was already less funded than in other countries, created an increasing problem of access and anger toward the NHS and its professionals. Moreover, changes in public attitudes (the NoVax movement outlined above is a good example) and a generalised distrust on the state and on doctors have fuelled a successful anti-institutionalist and anti-public health discourse by populist parties. 
In summary, our comparative study highlights that the metaphors of 'outsiders' and 'corrupt elites' provide a dormant motif for populism in all the five countries, yet they appear to have been mobilised towards populist end in very different ways. In particular, the examples of the rise of populism in Italy with its strong anti-expert rhetoric and anti-public health approach and the Turkish model with its strong anti-expert rhetoric and anti-doctor focus highlight a need to understand populist parties and policy discourses as a very serious threat to universal healthcare and the traditional role and status of professionals. Negative effects are also obvious in England, such as skill shortages and restriction of cross-border services and shared EU resources [53, p. 1122]. In Denmark and Germany, public health and the health professions currently do not seem to be a prime target of populist policy discourses, yet verbal and physical attacks on individual healthcare and emergency professionals are increasingly reported in the media. There is an urgent need for health policy, and for public health in particular, to respond more effectively to the proliferation of populist discourses [9] in order to both preserve the important role professional expertise in the delivery of healthcare and to retain the benefits of universal healthcare coverage.

\section{Limitations}

This study is to our knowledge the first effort to empirically investigate the relationship between healthcare governance, professions and populism in Europe. It is primarily driven by an urgent need to overcome a dangerous silence in the health policy and public health community. Despite some important warnings [3-10,58] there is a dearth of knowledge and both methodological approaches and data are lacking, which would allow for a systematic and comprehensive comparison. In this situation, our comparative study is of explanatory nature and has a number of important limitation. In particular, the analysis is based on strategic sampling and - in the absence of reliable typologies and data - the findings might look different for another country sample. Furthermore, the quantitative analysis is based on a number of different data sets which provided useful indicators for exploring our questions, but systematic selection or hypothesis-testing was not possible. It is important to keep the explanatory nature and the limitations in mind, when discussion the correlations we found between populisms,

professions and governance. These correlations must be treated with caution and do not provide information on causality. Moreover, they hopefully stimulate political debate and serve as a prelude for later studies that investigate causality. 


\section{Conclusions}

This article has set out to explore the relationship between healthcare governance, professions and populism. Our comparative analysis reveals that this relationship may take different forms in different countries. The cases of Denmark and Germany highlight institutional contexts that may serve as a bulwark against populist discourses. Abundant economic resources, networkbased governance and doctors participating as insiders in the policy process, together with high levels of trust in healthcare providers - and in the German case free choice of providers and sickness funds - appear to attenuate the ability of populist actors to promote a discourse which attacks healthcare services and the role played by the medical profession. On the other hand, an established and cherished NHS system with doctors as outsiders in the policy process and major NPM reforms together with low to medium levels of trust in healthcare providers may be fertile ground for populist discourse to grow and flourish, as, for instance, the rise of antivaccination movements in Italy show [59, 60], becoming a threat to public health. Our comparative study reveals correlations between healthcare governance, professions and populism which may serve as a basis for comprehensive comparative research. This could help to raise awareness in the population on the threats of growing populist movements in Europe and to support policymakers in building capacity to support health professional knowledge, healthcare and public health.

\section{References}

[1] Greer SL, Wismar M, Figueras J, editors. Strengthening health system governance: better policies, stronger performance. Maidenhead: Open University Press, 2016.

[2] Mackenbach JP, McKee M. Government, politics and health policy: a quantitative analysis of 30 European countries. Health Policy 2015; 119(10):1298-308.

[3] Greer S. Medicine, public health and the populist radical right, Journal of Royal Society of Medicine 2017; 110(8):305-8.

[4] McKee M, Galsworthy MJ. Brexit: a confused concept that threatens public health. Journal of Public Health 2016; 38:35.

[5] Speed E, Mannion R. The rise of post-truth populism in pluralist liberal democracies: challenges for health policy. International Journal of Health Policy and Management 2017; 6(5):249-51. 
[6] Speed E, Mannion R. The politics and power of populism: a response to the recent commentaries. International Journal of Health Policy and Management 2018; 7(4):365-3.

[7] Horton R. Why we must learn to love economists. The Lancet 2018; 391(10118):296.

[8] McKee M. Health professionals must uphold truth and human rights. European Journal of Public Health 2017; 27(1):6-7.

[9] McKee M, Stuckler D. 'Enemies of the people?' Public health in the era of populist politics. Comment on "The rise of post-truth populism in pluralist liberal democracies: challenges for health policy. International Journal of Health Policy and Management 2017; 6(11):669672.

[10] Schröder-Bäck P. Solidarität gegen das Absurde. Gesundheitswesen 2017; 79:525.

[11] World Health Summit. M8 Alliance Declaration World Health Summit 2017: Health is a political

choice; https://d1wjxwc5zmlmv4.cloudfront.net/fileadmin/user_upload/downloads/2017/WHS_B erlin/Data/M8_Alliance_Declaration_2017_Berlin.pdf; assessed 29 June 2018.

[12] Bertilsson M The welfare state, the professions and citizens, in Torstendahl R, Burrage M, editors. The formation of professions: knowledge, state and strategy. London: Sage, 1990, p. 114-33.

[13] Burau V. Governing through professional experts. In Dent M, Bourgeault IL, Denis J-L, Kuhlmann E, editors. The Routledge companion to the professions and professionalism. London: Routledge, 2016, p. 91-101.

[14] Harrison S, Mort M. Which champions, which people? Public and user involvement in healthcare as a technology of legitimation. Social Policy \& Administration 1998; 32(1):60_ 70.

[15] Hunter D. Health system transformation: engaging professions to make it happen. European Journal of Public Health. 2016; 26(Suppl. 1), 166.

[16] Kuhlmann E, Burau V. Strengthening stakeholder involvement in health workforce governance: why we need to talk about power. Journal of Health Services Research and Policy 2017; 23(1):66-8.

[17] Denis J-L, van Gestel N. Medical doctors in healthcare leadership. BMC Health Services Research 2016; 16(Suppl 2):158. 
[18] Kirkpatrick I, Kuhlmann E, Hartley K, Dent M, Lega F. Medicine and management in European hospitals: a comparative overview. BMC Health Services Research 2016; 16(Suppl 2):171.

[19] Numerato D, Salvatore D, Fattore G. The impact of management on medical professionalism: a review. Sociology of Health \& Illness 2011; 34:626-44.

[20] Tenbensel T, Burau V. Contrasting approaches to primary care performance governance in Denmark and New Zealand. Health Policy 2017; 121:853-61.

[21] Vicarelli G, Pavolini E. Dynamics between doctors and managers in the Italian National Healthcare System. Sociology of Health \& Illness 2017; 39(8):1381-97.

[22] Kuhlmann E, Burau V. 'Soft governance' and the knowledge-power bonds in professionalism. In Klenk T, Pavolini E, editors. Restructuring welfare governance: marketization, managerialism, and welfare state professionalism. Cheltenham: Elgar, 2015, p. 145-62.

[23] Davis P, Scott A, von Randow M. Health research sampling methods. In Saks M, Allsop, J, editors. Researching health. Qualitative, quantitative and mixed methods, second edition. London: Sage, 2012, p. 171-189.

[24] Agartan TI, Kuhlmann E. New Public Management, physicians and populism: A comparative analysis of healthcare systems and stakeholder involvement in Germany, Sweden and Turkey. Paper presented at the European Health Policy Group Autumn Meeting, London School of Hygiene and Tropical Medicine, 21-22 September 2017.

[25] Wismar M, Glinos IA, Sagan A, editors. Patients, peers, professionals: Skill-mix innovations and developments in primary and chronic care settings. Brussels: European Observatory on Health Systems and Policy, 2018.

[26] Blank RH, Burau V, Kuhlmann E (2018) Comparative health policy, fifth edition. Basingstoke: Palgrave.

[27] Panizza F. Populism and the mirror of democracy. In Panniza F, editor. Populism and the mirror of democracy. London: Verso, 2005, p. 1-31.

[28] Albertazzi D, McDonnell D. Twenty-first century populism. The spectre of Western European democracy. Basingstoke: Palgrave, 2011. 
[29] Andersen JG, Bjørklund T. Structural change and new cleavages: the Progress Parties in Denmark and Norway. Acta Sociologica 1990; 33(3):195-217.

[30] Mudde C, Kaltwasser CR. Populism: a very short introduction. Oxford: Oxford University Press, 2017.

[31] Speed E, Gabe J. The Health and Social Care Act for England 2012: the extension of 'new professionalism'. Critical Social Policy 2013; 33:564-74.

[32] Davis C. Drugs, cancer and end-of-life-care: a case study of pharmaceuticalization? Social Science \& Medicine 2015; 131:207-14.

[33] Kriesi H, Pappas TS, editors. European populism in the shadow of the Great Recession. Colchester: ECPR Press, 2015.

[34] WHO - World Health Organisation Regional Office for Europe. High-level regional meeting: health systems respond to NCDs: Experience of the European Region, Sitges, Spain, 16-18 April 2018. Briefing note for presenters and panellists. Copenhagen: WHO, 2018;

http://www.euro.who.int/_data/assets/pdf_file/0007/366766/HSS_NCD_briefing_note_ eng.pdf?ua=1; assessed 22 May 2018.

[35] Kuhlmann E, Groenewegen PP, Batenburg R, on behalf of the EUPHA HWR section. Why Europe needs stronger health workforce research. Consultation for the next EU Research and Innovation Programme, Statement on behalf of the European Public Health Association (EUPHA) section 'Health Workforce Research'. Utrecht: EUPHA, 2018; https://eupha.org/repository/advocacy/EU_Consultation_2018-

HWR_statement_for_circulation.pdf; assessed 22 May 2018.

[36] Kuhlmann E, Batenburg R, Wismar M, Dussault G, Maier CB, Glinos, IA, AzzopardiMuscat N, Bond C, Burau V, Correia T, Groenewegen PP, Hansen J, Hunter D, Khan U, Kluge H, Kroezen M, Leone C, Santic-Milicevic M, Sermeus W, Ungureanu M, for the EUPHA section Health Workforce Research. A call for action to establish a research agenda for building a future health workforce in Europe. BMC Health Research Policy and Systems 2018; 16:52.

[37] Birkhäuer J, Gaab J, Kossowsky J, Hasler S, Krummenacher P, Werner C, et al. Trust in the health care professional and health outcome: a meta-analysis. PLoS ONE 2017; 12(2):e0170988. 
[38] Putnam RD, Pharr SJ, editors. Disaffected democracies: what's troubling the trilateral democracies? New Jersey: Princeton University Press, 2000.

[39] Exworthy M, Mannion R, Powell M, editors. Dismantling the NHS? Evaluating the impact of health reforms. Bristol: Policy Press, 2016.

[40] Klein R. The New Politics of the NHS: from creation to reinvention. London: Radcliffe Publishing, 2013.

[41] Pavolini E, Guillèn A, editors. Public health care systems between restructuring and retrenchment. Institutional reforms and performance in EU countries. Basingstoke: Palgrave, 2013.

[42] Olejaz M, Juul Nielsen A, Rudkjøbing A, Okkels Birk H, Krasnik A, Hernández-Quevedo C. Denmark: health system review. Health Systems in Transition 2012; 14(2):1-192.

[43] Vrangbæk K. The Danish healthcare system. London: The Commonwealth Fund International Healthcare Systems Profile, 2015.

[44] Busse R, Blümel M, Knieps F, Bärnighausen T. Germany and health 1. Statutory health insurance in Germany: a health system shaped by 135 years of solidarity, self-governance, and competition, The Lancet 2017; 390:882-97.

[45] Wendt C, Agartan TI, Kaminska ME. Social health insurance without corporate actors: changes in self-regulation in Germany, Poland and Turkey. Social Science \& Medicine 2013; 86:88-95.

[46] Vicarelli G, Pavolini E. Health workforce governance in Italy. Health Policy 2015; 119(12):1606-612.

[47] Waring J. (2014) Restratification, hybridity and professional elites: questions of power, identity and relational contingency at the points of professional-organisational intersection. Sociology Compass 2014; 8(6):688-704.

[48] Agartan TI. Health workforce policy in Turkey's healthcare reform. Health Policy 2015; 119(12):1621-6.

[49] Atun R, Aydın S, Chakraborty S, Sümer S, Aran M, Gürol I, Nazlığlu S, Ozgülcü S, Aydoğan U, Ayar B, Dilmen U, Akdağ R. Universal health coverage in Turkey: enhancement of equity. The Lancet 2013; 382(9886):65-99.

[50] Bozkurt U. Neoliberalism with a human face. Science \& Society 2013; 77(3):372-96. 
[51] Van Ginneken E, Gray BH. European policies on healthcare for undocumented migrants. In Kuhlmann E, Blank RB, Bourgeault IL, Wendt C, editors. The Palgrave international handbook of healthcare and policy. Basingstoke: Palgrave, 2015, p. 631-48.

[52] Humpage L. A common sense of the times? Neo-liberalism and changing public opinion in New Zealand and the UK. Social Policy \& Administration 2016; 50(1):79-98.

[53] The Lancet. Editorial: Brexit and the NHS. The Lancet 2018; 391(10126):1122.

[54] Hanefield J, Mandeville K, Smith R. Making "health tourists" pay for care. British Medical Journal 2017; 356:j771.

[55] TMA (Turkish Medical Association) (2018) Press Release: Initiatives to make our professional association useless must end! [Meslek Örgütümüzü Isşlevsiz Kılmaya Yönelik Girişimlere $\quad$ Son $\quad$ Verilmelidir!] $\quad 6 \quad$ March 2018; http://www.ttb.org.tr/haber_goster.php?Guid=40517e38-2139-11e8-82e9-5e6c03ccf873; accessed 4 July 2018.

[56] Quotidiano Sanità. Vaccini. Salvini sì ai salvavita ma no a imporne 12 insieme. $17^{\text {th }}$ February 2018; www.quotidianosanità.it; accessed 4 July 2018.

[57] Pinar T, Acikel C, Pinar G, Karabulut E, Saygun M, Bariskin E, Cengiz M. Workplace violence in the health sector in Turkey: a national study. Journal of Interpersonal Violence 2017; 32(15):2345-65.

[58] Jarman H, McKee M, Hervey TK. Health, transatlantic trade and President Trump's populism: what an American Patients First has to do with Brexit and the NHS. The Lancet 2018; 392(10145):447-50.

[59] Riccardi W, Boccia S, Siliquini R. Moving towards compulsory vaccination: the Italian experience. European Journal of Public Health 2018; 28(1):2-3.

[60] Signorelli C, Guerra R, Siliquini R, Ricciardi W. Italy's response to vaccine hesitancy: an innovative and cost effective National Immunization Plan based on scientific evidence. Vaccine 2017; 35(33):4057-9. 